\title{
Mortgages, fixtures, fittings and security over personal property
}

Dr Sean Thomas

Senior Lecturer in Law, Durham Law School, Durham University*

\section{Introduction}

A mortgage is merely a disposition of an interest in property as security for a loan. ${ }^{1}$ This creates a deceptively simple problem: where should the line be drawn between providing protection for mortgagees and mortgagors of residential property?2 ${ }^{2}$ In the event of a breach of the mortgage agreement (usually due to default in repayment), the remedies of repossession and sale will likely be most significant for residential mortgagors. Although subject to cogent criticism, ${ }^{3}$ this right to repossess exists independently of statutory powers ${ }^{4}$ and is often (though not necessarily) the precursor to the right of sale. ${ }^{5}$ The power of sale can be based on the mortgage agreement, or implied by statute and, notably, it can be exercised regardless of the mortgagor's wishes. ${ }^{6}$ As such, residential mortgagors are 'especially vulnerable [in] that they have put the homes of

* An early version of this article was presented at the Socio-Legal Studies Association Conference, De Montford University, April 2012, and the author wishes to thank the participants for their useful comments. Particular thanks also go to Professor Adam Cygan and Barbara Bogusz for their help. Thanks also to the anonymous reviewers for their comments. The author is a member of the Secured Transactions Law Reform Project <http://securedtransactionslawreformproject.org $>$ and agrees with its aims and objectives, but this article represents the author's personal view and is not necessarily representative of the project's position on the matters discussed herein.

1 Santley $v$ Wilde [1899] 2 Ch 474, 474 (Lindley LJ); LPA, ss 87, 88, 91.

2 See e.g. P Omar, 'Recovery of Secured Property by Mortgagees: The Balance of Interests' (2005) 16 International Company and Commercial Law Review 445.

3 See e.g. M Dixon, 'Editor's Notebook' [2008] Conveyancer and Property Lawyer 474.

4 Four Maids Ltd v Dudley Marshall Ltd [1957] Ch 317, 320 (Harman J); Ropaigealach v Barclays Bank plc [2000] 1 QB 263; Horsham Properties Group Ltd v Clark [2008] EWHC 2327; [2009] 1 WLR 1255 (Ch).

5 LPA, s 91(2).

6 LPA, ss 101-03; Palk v Mortgage Services Funding plc [1993] Ch 330; Polonski v Lloyds Bank Mortgages Ltd (1998) 31 HLR 721. See also Trusts of Land and Trustees Act 1996, s 14(1). Cf. Financial Services Authority, Mortgages and Home Finance: Conduct of Business Sourcebook <http://www.fsa.gov.uk/pubs/hbreleases/rel112/rel112_MCOB.pdf > (accessed 17 December 2015) suggesting a minimum of two months' arrears before bringing proceedings. 
themselves and their families at risk by entering into the mortgage', ${ }^{7}$ which is problematic as the law generally favours mortgagees. ${ }^{8}$

As goods may be attached to land, along a spectrum of affixation, ${ }^{9}$ there is a complex sub-problem: if a mortgagee can sell mortgaged property, to what extent does that power extend to goods associated with the property? Although mortgages of realty need to be in writing and registered, ${ }^{10}$ the details of the mortgage agreement will not be registered even though such details may seemingly give the mortgagee such a power to control, acquire or sell goods associated with the realty. Ascertaining such details requires direct enquiry of the lender or (possibly) the borrower. ${ }^{11}$ However, 'mortgages have always pretended to a greater or less degree to be something they are not'. ${ }^{12}$

Consider the HSBC Bank plc Mortgage Deed Conditions (2006 edition). ${ }^{13}$ In the definition section, condition 1(e) defines 'Property' as 'the whole or any part of the Property described in the Mortgage (including all buildings, fixtures and fittings on the Property now, or at any time after the date of the Mortgage)'. Condition 1(f) defines 'Assets' as 'anything and everything charged, assigned or transferred by the Mortgage'. In the section entitled 'Looking after the Property', condition 5(c) states that the mortgagor must not, without the bank's written consent '(i) . . . remove or detach any fixture or fitting; or (ii) remove or detach any plant or machinery which belongs to, or is used by, you (except for replacement or repair)'. Condition 5(d) states that: 'If you, or anyone else, removes or detaches any fixture, fitting, plant or machinery or, if any is destroyed or damaged, you must immediately replace or repair it with one of the same or better quality.' In the section entitled 'Safeguarding the Bank's Security', condition 9(d) states that the mortgagor 'must not, without the Bank's written consent, at any time create or allow any other mortgage, charge or burden in relation to the Assets'. In the event of the appointment of a receiver, the mortgage deed states in condition 13(a) that the receiver has the power 'to sell, exchange, lease or in any other way dispose of the Assets in the manner and generally on terms the receiver thinks fit in your name and on your behalf' and, under 13(b), the power 'to do anything an absolute owner could do with the Assets'.

7 Law Commission, Transfer of Land: Land Mortgages Law Com No 204 (1991) [4.5].

8 C Davis, 'Giving with One Hand and Taking Away with the Other: How Far Can a Mortgagor Insist on Selling his Property?' (1998) 1 Journal of Housing Law 56; M Dixon, 'Combating the Mortgagee's Right to Possession: New Hope for the Mortgagor in Chains?' (1998) 18 Legal Studies 279; M Davey, 'Insolvency and the Family Home' [2000] Insolvency Lawyer 2; L Fox, Conceptualising Home: Theories, Laws and Policies (Hart 2007) ch 1; S Bright, 'Dispossession for Arrears: The Weight of Home in English Law' in L Fox O’Mahony and J A Sweeney (eds), The Idea of Home in Law: Displacement and Dispossession (Ashgate 2011) ch 2. Cf. F O Adeoye, 'The Anglo-American Law of Mortgagees: A Quagmire for Creditors' [1993] Journal of Business Law 544, arguing that the law has shifted too far in restricting mortgagees.

9 See e.g. Elitestone Ltd v Morris [1997] 1 WLR 687; cf. P Luther, 'The Foundations of Elitestone' (2008) 28 Legal Studies 574.

10 Law of Property (Miscellaneous Provisions) Act 1989, s 2; Land Registration Act 2002, ss 27-30.

11 There is a lack of clarity as to obligation on mortgagees or mortgagors vis-à-vis registration of the mortgage. The Land Registration Rules 2003, r 9, states, inter alia, that: 'The charges register of a registered estate must contain, where appropriate (a) details of . . charges, and any other interests which adversely affect the registered estate subsisting at the time of first registration of the estate or created thereafter, (b) any dealings with the interests referred to in paragraph (a), or affecting their priority, which are capable of being noted on the register, (c) sufficient details to enable any registered charge to be identified'.

12 A W B Simpson, A History of the Land Law 2nd edn (OUP 1986), 242. F W Maitland, Equity 2nd rev edn (CUP 1936) 182: the mortgage deed is 'one long suppression veri and suggestion falsi.

13 This was supplied to the author in pursuance of an application for mortgaged financing for the purchase of a residential property. Copy on file with the author. 
There is also a section entitled 'Items left at the Property', in which condition 22 states:

(a) At any time after the Mortgage has become enforceable, the Bank or any receiver may (but having no duty or liability to you to do so) as your agent and at your expense, remove, store, preserve, sell or otherwise deal with any furniture, goods, vehicles, plant or machinery or other chattels or produce, crops or animals which you fail or refuse to remove from the Property. (b) Neither the Bank nor any receiver will be liable for any resulting loss or damage. (c) So far as may be lawful, the Bank may set-off any sums realised on any sale against the [mortgage] Debt.

In essence, this deed provides that, in the event of default and repossession, HSBC is entitled to such effective control of all goods on or in the land that they might as well be considered as claiming ownership of the goods. ${ }^{14}$ The underlying purpose of the mortgage agreement's extension into personal property may just be to enable effective control of the real property in the event of default. ${ }^{15}$ However, the legal effect of this approach gives rise to a problematic question: who truly owns goods in residential properties, where the goods are acquired after a purchase-price mortgage is granted?

At first sight, the answer is obvious. Subject to an expressed contrary intention, ${ }^{16}$ a conveyance 'shall be deemed to include and shall by virtue of this Act operate to convey, with the land, all . . . fixtures' ${ }^{17}$ Leading texts follow this by noting that fixtures are goods which, according to the degree and purpose of their annexation to the land, lose their identity as goods and become part of the land. ${ }^{18}$ Immediately after making this point, one such text noted that, ' $[\mathrm{r}]$ ights of foreclosure, possession and statutory rights of sale extend to the interest in any fixtures or personal chattels affected by the mortgage'. ${ }^{19}$ The distinction between fixtures and goods 'affected by the mortgage' is unclear. For example, in Whitley $v$ Challis, concerning a claim that certain words in a conveyance brought goodwill (i.e. personal property) within the scope of mortgage of realty, Lindley LJ said such words 'cannot have the effect of bringing in property which the mortgagor had not agreed to mortgage ... [for otherwise is to allow a claim] ... to obtain an enlargement of that security, and to get a benefit to which [the mortgagee] is not entitled'. ${ }^{20}$ Therefore, one security interest (a mortgage over land) cannot beget another security interest (over goods held by the residential mortgagor).

The Law Commission has consistently failed to examine this issue, ${ }^{21}$ even though it has recognised that the 'contact and overlap' between systems for mortgages over land and systems covering other property meant that 'conflicting or inconvenient results' need

14 Other lenders are more explicit. The Halifax Mortgage Conditions 2011, at page 38 states: 'How we can deal with things left in your property[:] If we take possession of your property, we may remove, store, sell or dispose of anything you leave at your property (including animals). We will do this as your "agent". You will have to pay our costs of doing this.'

15 See $n 94$ and accompanying text.

16 LPA, s 62(4). A conveyance includes a mortgage: LPA, s 205(1)(ii).

17 LPA, s 62(1). This may be an example of how principles of accession reduced transaction costs in the transfer of property: T W Merrill, 'Accession and Original Ownership' (2009) 1 Journal of Legal Analysis 459, 485-86.

18 See e.g. E F Cousins and I Clarke, Cousins on the Law of Mortgages (Sweet \& Maxwell 2010) [15-01]; C Harpum, S Bridge and M Dixon, Megarry and Wade: The Law of Real Property 7th edn (Sweet \& Maxwell 2008) [23002]-[23-003].

19 Cousins and Clarke (n 18) [15-01], citing the LPA, s 88(4), s 89(4); Cross v Barnes (1877) 36 LT 693; and Re Rogerstone Brick and Stone Co Ltd [1919] 1 Ch 110.

20 [1892] $1 \mathrm{Ch}$ 64, 69.

21 Law Commission (n 7); Law Commission, Company Security Interests Law Com No 296 (2005) xiv. 
to be avoided. ${ }^{22}$ There was also no consideration of this point in the recent Ministry of Justice consultation paper, Mortgages: Powers of Sale and Residential Property. ${ }^{23}$ Likewise, this issue is not considered in the very recent Law Commission consultation paper on reforming the law on bills of sale. ${ }^{24}$ To avoid perpetuating misunderstanding, ${ }^{25}$ the extent to which a mortgage over realty can capture or control personal property needs deeper exploration. ${ }^{26} \mathrm{It}$ is on the one hand an issue of principle, ${ }^{27}$ but it may also be an issue of money, as certain goods that occupy the 'twilight zone' 28 between fixtures and fittings may be highly valuable (such as a range-style cooker/heater like an Aga, or a fish tank and assorted accoutrements). Further complexities may arise regarding the status of new technologies and their place within the home. ${ }^{29}$ It should also be noted that the HSBC deed also covered animals, and there have recently been complicated disputes concerning the rights of mortgagees to deal with animals held both commercially, ${ }^{30}$ and domestically. ${ }^{31}$

This article will demonstrate how the doctrine on fixtures and fittings was developed to avoid difficulties with the bills of sale regime in the context of non-residential commercial mortgage transactions. As a result, mortgagees of realty were able to exert ownership-like control over personal property. The shift in focus in the bills of sale regime from creditor to debtor protection had no impact on this use of the fixtures doctrine, thus rendering the overwhelmingly commercial nature of the law on fixtures and fittings inappropriate for residential consumer purchase-money mortgages. ${ }^{32}$ As such, merely resting our understanding of the relationship between goods and land on a doctrine that goods affixed to land lose their status as goods and become part of the land

22 In Law Commission, Land Mortgages Law Com Working Paper 99 (1986) [1.4]. The non-coverage of personal property security interests by the Law Commission in 1986 was due to the concurrent work by Professor Diamond: A Diamond, A Review of Security Interests in Property (HMSO 1989).

23 Consultation Paper CP55/09, 29 December 2009.

24 Law Commission, Bills of Sale: A Consultation Paper Law Com CP 225 (2015); see also n 193 and following text.

25 Cf. G Watt, 'The Lie of the Land: Mortgage Law as Legal Fiction' in E Cooke (ed), Modern Studies in Property Law vol 4 (Hart 2007) ch 4.

26 As to the importance of control over property, see generally P DiCola, 'Valuing Control' (2015) 113 Michigan Law Review 663.

27 D L Carey Miller, 'Fixtures and Auxiliary Items: Are Recent Decisions Blurring Real and Personal Rights?' (1984) 101 South African Law Journal 205, 207. For a recent comparative analysis, see L P W van Vliet, 'Accession of Movables to Land: I' (2002) 6 Edinburgh Law Review 67; 'Accession of Movables to Land: II' (2002) 6 Edinburgh Law Review 199. However, for both Carey Miller and van Vliet, the focus of their work was clearly on commercial issues, with little concentrated focus on the issues concerning residential purchasemoney mortgages. Moreover, a common law perspective may result in different analysis.

28 Cf. M R Friedman, 'The Scope of Mortgage Liens on Fixtures and Personal Property in New York' (1938) 7 Fordham Law Review 331, 331: 'Occupying a twilight zone between real and personal property the area of fixtures is one which defies precise metes and bounds.'

29 This is further complicated by the potential of an internet of things, and the problems in the current law on sale of goods: see e.g. S Thomas, 'Goods with Embedded Software: Obligations under Section 12 of the Sale of Goods Act 1979’ (2012) 26 International Review of Law, Computers and Technology 165.

30 National Westminster Bank v Hunter [2011] EWHC 3170 (Ch), discussed at n 75.

31 Campbell v Redstone Mortgages Ltd [2014] EWHC 3081 (Ch) (power to remove animals held at an informal sanctuary).

32 The term 'consumer' here means 'persons who borrow for private purposes not related at all to their business, trade or profession', following the approach in Law Commission, Registration of Security Interests: Company Charges and Property Other than Land Law Com CP 164 (2002) [8.4]. See also Ministry of Justice, Mortgages: Powers of Sale and Residential Property Consultation Paper CP55/09 (29 December 2009) [22]. This article will not consider the special position of agricultural land and fixtures thereto, for which see e.g. Agricultural Holdings Act 1986, s 10; Agricultural Tenancies Act 1995, s 8. 
is insufficient to explain and continually justify the potential power mortgagees appear to have acquired. This article will argue for a narrower construction of mortgagees' powers of control over goods.

\section{Mortgages of land and fixtures}

Although 'determining when an object which was formerly a chattel has become part of land, is recognised to be complex and confusing', there are basic principles. ${ }^{33}$ In the leading case Holland $v$ Hodgson, Blackburn J said that the general principle quicquid planatur solo, solo cedit (whatever is attached to land becomes part of the land itself) was 'the general maxim of the law', 34 and it remains 'the foundation of the modern law of fixtures'. 35 This principle obviously affects the mortgage relationship, 36 as well as third-party rights: if fixtures pass to the mortgagee, a trustee in bankruptcy of the mortgagor is not entitled to those 'goods'. ${ }^{37}$ However, as Cousins and Clarke recognise, this principle merely 'provides a good starting point for the consideration of the relationship between fixtures and mortgages of the land to which they are affixed'. ${ }^{38}$ It is suggested that this claim of a general principle masks a historical pattern of doctrinal development focused on nonresidential commercial mortgages and ignores the impact of the bills of sale regime. The law is incoherent and uncertain, 'unduly cumbersome' and relies on 'anachronistic rules and case-law'. ${ }^{39}$ This makes attempts to simply apply the doctrine to residential mortgagors highly problematic.

\subsection{THE LEADING CASES ON FIXTURES}

From the sixteenth century, English law distinguished between owners in fee simple and tenants with regard to fixtures: tenants were able to remove items (during the term) which had been affixed to the land. ${ }^{40}$ The status of 'trade fixtures . . . remained in doubt until the 17 th century', though by the eighteenth century tenants could remove them for the benefit of trade and commerce: ${ }^{41}$ around the same time the tenant's right to remove ornamental and domestic fixtures developed. ${ }^{42}$ The extension of this exception (for trade

33 P Luther, 'Fixtures and Chattels: A Question of More or Less' (2004) 24 Oxford Journal of Legal Studies 597, 597. On the difficulty of reconciling the case law on fixtures, see also Reynolds v Ashby [1904] AC 466, 473-74 (Lord Lindley).

34 Holland v Hodgson (1872) LR 7 CP 328. For the history of the use of this maxim in English law, see Luther (n 33) 598-601.

35 M Haley, 'Case Comment: The Law of Fixtures: An Unprincipled Metamorphosis?’ [1998] Conveyancer and Property Lawyer 137, 137.

36 Cousins and Clarke (n 18) [15-01]: 'The rule applies to all fixtures which are the subject matter of legal or an equitable mortgages [citing Re Lusty (1889) 60 LT 160] of freehold or leasehold land [citing Meux v Jacobs (1875) LR 7 App Cas 481; Southport and West Lancashire Banking Co v Thompson (1887) 37 Ch D 64, approved in National Provincial and Union Bank of England v Charnley [1924] 1 KB 431]'.

37 Clark v Crownshaw (1832) 3 B \& Ad 804; 110 ER 295 (not entitled to the fixtures, but entitled to the otherwise movable goods); Ashton v Blackshaw (1869-70) LR 9 Eq 510 (assignment of furniture within the scope of the Bills of Sale Acts and, thus, as an unregistered bill of sale the assignment was void, otherwise the goods would be secured for the plaintiff's use).

38 Cf. Cousins and Clarke (n 18) [15-01].

39 Haley (n 35) 144.

40 Luther (n 33) 601-02. See also Sir John Baker, The Oxford History of the Laws of England: volume VI 1483-1558 (OUP 2003) 735-38; Simpson (n 12) 242-43. The nature of actions as to personal or real property must have played a role: Simpson (n 12) chs X and XI and Baker, ch 39. Economy unfortunately prevents a full examination of this history.

41 Luther (n 33) 602.

42 Ibid 606. 
fixtures) to heirs did not have solid foundations ${ }^{43}$ and for well into the nineteenth century the key determining factor for fixtures held by someone other than a tenant was the degree of annexation rather than any particular right. ${ }^{44}$ Yet, whilst the distinction between tenants and mortgagors as to their rights over fixtures was clearly evident in Holland $v$ Hodgson in $1872,{ }^{45}$ by 1887 it had more or less dissipated. ${ }^{46}$

In Holland $v$ Hodgson the object (or purpose) of the annexation test, as central to determining whether goods became affixed to land, was crystallised. ${ }^{47}$ Luther correctly argues that this test was actually a novel combination of different tests, ${ }^{48}$ but its effect was to distinguish between the extent to which assets could be removed (which depended on the object of annexation) and whether the assets attached to the land in the first place (which turned on the degree of annexation), which in turn focused judicial attention on the commercial importance of security for mortgagees of industrial property. ${ }^{49}$ Such creditors were more interested in the extent to which they could protect and enhance their interest by acquiring, if necessary, the annexed asset. However, a close reading of Holland reveals it actually had little to do with settling a coherent test for fixtures and fittings. 50 Moreover, although there were clear references by Blackburn J as to the importance of party intention, ${ }^{51}$ intention became secondary to the test of the manner by which goods were attached. ${ }^{52}$ At the turn of the nineteenth century, the irrelevance of intention became apparent in the Court of Appeal decision Hobson $v$ Gorringe, 53 and the House of Lords case Reynolds $v$ Ashby. ${ }^{54}$ At the end of the twentieth century, the House of Lords, in Melluish v BMI (No 3) Ltd ${ }^{55}$ and Elitestone Ltd v Morris, ${ }^{56}$ reiterated that approach. These four leading cases indicate that the key test to determine the extent of a mortgagee's rights is simply whether the goods have become fixtures. Party intention vis-à-vis ownership of the goods is essentially irrelevant even where the ownership of the goods resides with a third party. However, the authority of these decisions in non-commercial situations is dubious at best.

In Gough v Wood \& $\mathrm{Co}^{57}$ the defendants agreed to supply a tenant with a boiler for the purposes of the tenant's business, with the property in the boiler remaining with the defendants until all instalments were paid and with a right of removal in the event of default. The tenant mortgaged his interest in the land to the plaintiff, who did not know of the prior transaction. Following this, the boiler was affixed to the land. Upon default the defendants removed the boiler. It was held that the mortgagee must have acquiesced in the mortgagor fixing and removing fixtures for the purpose of trade. The importance

43 Luther (n 33) 603-04.

44 Ibid 605.

45 Holland v Hodgson (1872) LR 7 CP 328, 333. See also e.g. Exparte Dalglish (1872-73) LR 8 Ch App 1072.

46 Southport and West Lancashire Banking Cov Thompson (1887) LR 37 ChD 64. See also Reynolds v Ashby [1904] AC 466, 473 (Lord Lindley).

47 (1872) LR 7 CP 328, 334-35 (Blackburn J).

48 Luther (n 33) 601-05. See also Hellawell v Eastwood (1851) 6 Ex 295, 312-313; 155 ER 554, 561 (Parke B).

49 Luther (n 33) 612-14.

50 See text following $\mathrm{n} 93$.

51 (1872) LR 7 CP 328, 335: 'if the intention is apparent to make the articles part of the land, they do become part of the land: see D'Eyncourt v Gregory [(1866) LR 3 Eq 382].'

52 Luther (n 33) 615-18.

53 [1897] 1 Ch 182.

54 [1904] AC 466.

55 [1996] AC 454.

56 [1997] 1 WLR 687.

57 [1894] 1 QB 713. 
of this implied acquiescence to mortgagors acting in the course of business is clear in 'the principal case': 58 Hobson $v$ Gorringe. 59

In Hobson the mortgagor acquired a gas engine under a hire-purchase scheme, prior to the mortgage. The engine was attached to freehold land by bolts and screws (to prevent it moving during use) and was used by the mortgagor for the purposes of his trade. The mortgagee had no knowledge of the hire-purchase. Upon default, the mortgagee took possession whilst the engine was still on the land. A L Smith LJ said:

[If the machine] always remained a chattel, [it would have] consequently never passed to Gorringe as mortgagee of the land. It obviously did not pass to him as a chattel under the mortgage to him of 'fixed machinery', for, if a chattel, it ever remained Hobson's [the seller], and never was the property of King [the mortgagor/hirer]; and unless Mr. Gorringe takes the engine as part of the land mortgaged to him he does not take it at all. ${ }^{60}$

As the engine was attached to the land, the mortgagee had priority. The intention, evidenced in the hire-purchase agreement, that the engine would remain goods could not override the affixation of the goods. This was partly because Hobson's right to remove the engine on default was not of the nature of legal or equitable rights in land that could take priority over a third party. ${ }^{61}$ The other aspect of the decision was:

That a person can agree to affix a chattel to the soil of another so that it becomes part of that other's freehold upon the terms that the one shall be at liberty in certain events to retake possession we do not doubt, but how a de facto fixture becomes not a fixture or is not a fixture as regards a purchaser of land for value without notice by reason of some bargain between the affixers we do not understand, nor has any authority to support this contention been adduced. ${ }^{62}$

The fact that Hobson had failed to remove the engine prior to the mortgagee's claim was enough to dispose of the case. The court did not explain what distinguished the insufficiency of the agreement between the vendor and vendee (on the grounds its content was unknown to the mortgagee) and the sufficiency of the agreement between mortgagor and mortgagee (even though its contents were equally unknown as to the vendor).

The Court of Appeal would face similar issues three years later in Monti v Barnes. ${ }^{63}$ Unusually, this case concerned a residential mortgage. The owner of a residential house mortgaged the property in 1890, the mortgage being transferred to the defendant in 1893 . Later in 1893 the owner sold the equity of redemption in the mortgage, and also the furniture, fittings and effects therein, to the plaintiff. In 1898 the defendant foreclosed the mortgage and became owner in fee of the house. The original mortgagor had removed certain grates (used to hold solid fuel) and replaced them with 'dog grates', a particularly heavy type. The plaintiff-mortgagor had removed the dog grates; the defendantmortgagee claimed this was a wrongful detention. If these dog grates were fixtures, they would pass to the mortgagee.

A L Smith MR focused on the weight of the grates and also 'the intention with which the mortgagor placed the dog grates in the house, [for] it is obvious that he could not

58 Reynolds v Ashby [1904] AC 466, 471 (Lord James).

59 [1897] Ch 182.

60 Ibid 189.

61 Ibid 192 (A L Smith LJ).

62 Ibid 195 (A L Smith LJ).

63 [1901] 1 QB 205. 
have intended that the house should be without grates; and I have no doubt that the dog grates were put in to fill the place of the old fixed grates, which he took out, and to pass with the inheritance'. ${ }^{64}$ Collins LJ recognised that this dispute 'differs widely from that of landlord and tenant'. ${ }^{65}$ As such a 'mortgagor [who brought] an article on to the mortgaged premises, although it may be after the mortgage, would generally not regard the premises as belonging to any one but himself, and would therefore be the more likely to intend the article to be for the improvement of the property from which he does not contemplate being ousted'. ${ }^{66}$ Stirling LJ thought that:

it is most material to observe that [the dog grates] were placed there by the mortgagor after the mortgage, and in the place of the old fixed grates which existed at the time of the mortgage. It seems to me that, if the mortgagor had removed the old grates without substituting any grates for them, he would have been guilty of waste, such as would call for the interference of the Court at the instance of the mortgagee. ${ }^{67}$

Although Monti appears very similar to the residential mortgage situation at the heart of this article, it cannot support the broader claim that all goods which attach to the realty must pass to the mortgagee as it was accepted that dog grates were an improvement of the realty. It is this which explains the references to intention in Monti. However, it was the mortgagor's intentions alone which the court took into account, not the intention of all relevant parties. Furthermore, it was the mortgagor's intention in his capacity as mortgagor of realty, and not as owner of personality, that was taken as relevant. Moreover, the reference to waste by Stirling LJ and the distinction drawn with a tenancy by Collins LJ suggests Monti was the last convulsion of the freehold/leasehold distinction that had previously dominated these sorts of disputes. At this point it is necessary to return to the development of fixtures law per se and the important decision in Reynolds $v$ Ashby. ${ }^{68}$

In Reynolds the House of Lords held that where a machine, acquired by hire-purchase, had been attached to land by means of nuts and bolts, the mortgagee took priority over the seller of the machine when the hirer defaulted, as the machine had become part of the land. The fact that hire-purchase meant the appellant retained title to the goods could not override the fact that 'machines were sold by the appellant for the purpose of being used in the manner in which they were used. In order so to use them it was necessary that they should be fixed, and so become part of the building.' ${ }^{69}$ As Lord Lindley put it: '[i]t is true that the machines could be removed if necessary, but the concrete beds and bolts prepared for them negative any idea of treating the machines when fixed as movable chattels'. ${ }^{70}$

For Lord Lindley, the best approach for dealing with fixtures was to pay attention 'not only to the nature of the thing and to the mode of attachment, but to the circumstances under which it was attached, the purpose to be served, and last but not least to the position of the rival claimants to the things in dispute'. ${ }^{71}$ This final element is important:

64 Monti (n 63) 207.

65 Ibid 208.

66 Hobson v Gorringe [1897] Ch 182208.

67 Ibid 209.

68 [1904] AC 466.

69 Ibid 472 (Lord James).

70 Ibid.

71 Ibid 474. 
assessing the relative priority of the parties to the dispute, which could be undertaken in an objective fashion, is substantially different to assessing subjective intentions and opens a gap for policy-based analysis premised on the importance of smoothing the free flow of credit. However, Lord Lindley was content to hold that the vendor of the goods knew of the mortgage and knew of the risks involved and so could be held to run the risk that the machine sold would become a fixture. Either the vendor effectively authorised the conversion of the goods into fixtures, or he had lost the right to repossess the goods by failing to exercise the right prior to the mortgagee taking possession. ${ }^{72}$

The shift in the focus of judicial analysis, from attachment per se to the purpose and use of the goods, ${ }^{73}$ enables a more contextual approach, but it still does not mean that intention is relevant, as the purpose and use of goods can be ascertained objectively. ${ }^{74}$ Furthermore, the importance of the disponer's failure to re-acquire the goods prior to the mortgagee taking possession of the realty (regardless of any contractual intention otherwise) remained significant. This much can be seen from the important duo of cases in the House of Lords in the 1990s. In Melluish v BMI (No 3) Ltd, ${ }^{75}$ leasing companies claimed a tax reduction based on their retention of ownership of boilers that had been installed, under lease arrangements with local authorities, in local authority housing. The agreement between the parties as to the ownership of the boilers could not override the principle effect of annexation, i.e. the necessary extinction of their status as goods, ${ }^{76}$ even if the lease agreements provided the lease companies with a right to retake possession in the event of default. Lord Browne-Wilkinson said:

The terms expressly or implicitly agreed between the fixer of the chattel and the owner of the land cannot affect the determination of the question whether, in law, the chattel has become a fixture and therefore in law belongs to the owner of the soil... The terms of such agreement will regulate the contractual rights to sever the chattel from the land as between the parties to that contract and, where an equitable right is conferred by the contract, as against certain third parties. But such agreement cannot prevent the chattel, once fixed, becoming in law part of the land and as such owned by the owner of the land so long as it remains fixed. ${ }^{77}$

The following year saw Elitestone Ltd $v$ Morris, ${ }^{78}$ concerning a wooden chalet which rested on concrete pillars attached to the ground such that it could only be removed from the land by demolition. The claimant owned the freehold; the defendant occupied the chalet under a purported licence. The claimant brought proceedings to obtain possession of the land. The defendant claimed he was a protected tenant under the Rent Act 1977, s 1. The House of Lords held that the chalet's construction was such that an objective assessment

72 Reynolds (n 68) 475.

73 The question of attachment per se could still be relevant though: see e.g. Hulme v Brigham [1943] 1 KB 152.

74 Thus, the different results in Lyon \& Co v London City and Midland Bank [1903] 2 KB 135 (treated as sui generis in Reynolds v Ashby [1904] AC 466, 474 (Lord Lindley)) and Vaudeville Electric Cinema v Muriset [1923] 2 Ch 74 (where Sargant J (at 87) distinguished Lyon \& Co).

75 [1996] 1 AC 454.

76 Ibid 473 (Lord Browne-Wilkinson).

77 Ibid. See also e.g. Cousins and Clarke (n 18) [15-02]: 'If chattels which are bailed under a hire or hire-purchase agreement, or are agreed to be sold under a conditional sale agreement, become fixtures (other than trade fixtures) they become subject to the mortgage even if affixed after it was created.' The reference supporting this statement (fn 12) merely states: 'As to whether a chattel has become a fixture, see Holland $v$ Hodgson (1872) LR 7 CP 328; Crossley Bros v Lee [1908] 1 KB 86 [a gas engine let out on hire, affixed to the floor of business premises by bolts and screws, was held to be a fixture].'

78 [1997] 1 WLR 687. 
would indicate that it could not have remained a chattel, but must have been intended (regardless of the common assumption of both parties that the chalet was Morris's personal property) to form part of the realty. This meant that Morris succeeded, as the chalet was held to be part of the land and thus the Rent Act 1977 applied.

This conclusion was reached by virtue of application of the two-part test expressed by Blackburn J, i.e. it depended on the degree and object of annexation to the land. ${ }^{79}$ Lord Lloyd followed Lord Browne-Wilkinson's speech in Melluish and said '[i]f an express agreement cannot prevent a chattel from becoming part of the land, so long as it is fixed to the land, it is obvious that a common assumption cannot have that effect'. ${ }^{80}$ Similarly, Lord Clyde held that:

... [i]t is the purpose which the object is serving which has to be regarded, not the purpose of the person who put it there. The question is whether the object is designed for the use or enjoyment of the land or for the more complete or convenient use or enjoyment of the thing itself. 81

Thus, the purpose goods serve determines whether they become part of the realty, and any prior contract between the disponer of goods and a disponee will be insufficient to negate the effect of that purpose. All we really know from Melluish and Elitestone is that the disponer of goods has to remove the goods prior to the land being repossessed to avoid losing any pre-existing interest in the asset, which repeats the analysis in Hobson and Reynolds. ${ }^{82}$ However, neither decision engaged with Lord Lindley's analysis in Reynolds $v$ Ashby, specifically the third limb: 'the position of the rival claimants to the things in dispute'. ${ }^{83}$ In Melluish, Lord Browne-Wilkinson appeared to rely entirely on Hobson $v$ Gorringe and only referred to Reynolds to note that it approved Hobson, ${ }^{84}$ which was replicated in Elitestone. 85 The position of the residential mortgagor cannot be accurately ascertained. Neither Melluish nor Elitestone involved a residential consumer purchasemoney mortgage (or indeed even a mortgage at all), and Gough and Hobson concerned situations where goods were acquired and attached (whether sufficient to qualify as a fixture or not) prior to the mortgage. Reynolds did involve a post-mortgage acquisition of goods, but it too was in a commercial context. The only non-commercial case, Monti, is best treated as an anachronistic outlier.

\subsection{Application IN RECENT CASE LAW}

The lack of direction from the leading cases as to the extent of a mortgagee's powers of control over goods in consumer cases may explain the nature of the reasoning in two cases which were much more relevant for the problem at hand and which were decided in between the House of Lords decisions in Melluish and Elitestone. ${ }^{86}$

79 There is a different aspect to Elitestone, concerning the application of a three-fold approach to goods, fixtures and things that are part and parcel of the land itself, for which see P Luther, 'The Foundations of Elitestone' (2008) 28 Legal Studies 574. For recent application of Elitestone in a dispute concerning a Henry Moore sculpture, see Tower Hamlets LBC v Bromley LBC [2015] EWHC 1954 (Ch)

80 [1997] 1 WLR 687, 690.

81 Ibid 698.

82 Arguably, it also replicated an implicit consequence of the decision in Monti: had the mortgagee there removed the dog grates before the mortgagor the case would not have arisen.

83 [1904] AC 466, 474.

84 [1996] 1 AC 454, 473-75.

85 [1997] 1 WLR 687, 693 (Lord Lloyd), 698 (Lord Clyde).

86 The order of hearings was Melluish, Botham, Deutsche Genossenchafts Hypothekenbank, then Elitestone. 
In Deutsche Genossenchafts Hypothekenbank v Amstad, 87 the claimant bank lent money to Amstad on terms described as 'a legal mortgage on the pledged property'. ${ }^{88}$ The loan concerned a mortgage over land and not a charge over personal property. ${ }^{89}$ Following default, the claimant appeared to appoint a receiver. Harman J stated that, whilst this is perfectly acceptable under the Law of Property Act 1925 (LPA) with regard to mortgaged real property:

there is no doubt that chattels in the freehold property do not pass to the mortgagee under his legal charge. He has no rights over chattels, and the Receiver is not entitled to take into his possession any chattels there may be. In a normal private mortgage of a house to a lender, whether a bank or a building society or a private individual — it matters not — for which a normal legal charge such as this is given, there has never been any suggestion that the curtains, carpets, beds, sofas, chairs, china, cutlery and other chattels in any normal home would pass under the legal mortgage or would be available to the Law of Property Act Receivers appointed in respect of such a mortgage. ${ }^{90}$

Thus, the receiver had no right to take possession of the goods. ${ }^{91}$ Harman $J$ refused to declare such goods were part of the charge, because they were not fixtures, ${ }^{92}$ and the agreement between the bank and Amstad did not meet the 'normal requirements' of a floating charge or provide for a fixed charge. ${ }^{93}$

Around the same time, the Court of Appeal was considering similar issues in Botham $v$ TSB Bank. ${ }^{94}$ Botham owned a flat subject to a mortgage in favour of the TSB Bank. Upon default the bank repossessed and eventually sold the flat, but there remained a shortfall of some $f, 170,000$. Botham and the bank disputed the status of goods in the flat. It was agreed the 109 separate goods could be classified in the following manner: 'fitted carpets; light fittings; gas fires; curtains and blinds; fittings on sanitary ware; bathroom accessories; mirrors and marble panels; kitchen units, work surfaces and sink; and major kitchen appliances (so called "white goods"). 95 At first instance these goods were found to be fixtures and part of the land (apart from a wall-mounted electric razor), on the basis of the degree and purpose of annexation (with the modern emphasis being on the purpose of annexation). Nevertheless, a close examination of what the judges actually said raises various intriguing questions.

Sir Richard Scott VC 'recognised the danger in applying too literally tests formed in old cases dealing with machinery in factories to cases regarding articles in residences'. He was also wary of 'applying tests formulated for the purpose of decisions relating to ornamental items to cases relating to articles of utility'. ${ }^{96} \mathrm{He}$ also noted that the intrinsic value of the goods, and their aesthetic value, would be of at most minimal significance.

87 Ch D, 22 January 1997. This case is cited as authority for the statement that 'a mortgage of realty normally obtains no security over chattels (e.g. furniture) in or on the mortgaged property' in K Gray and S F Gray, Elements of Land Law 5th edn (OUP 2009) [1.2.47], fn 2.

Ch D, 22 January 1997, 1.

89 Ibid 2.

90 Ibid 3.

91 The point of this action seemed to be that the receiver was attempting to claim an interest in goods which Amstad had actually sold to and leased back from a Mr Stone.

92 Ch D, 22 January 1997, 4.

93 Ibid 5.

94 (1997) 73 P \& CR D1 (CA).

95 Ibid D1-D2.

96 Ibid D2. 
Roch LJ took the approach that goods necessary for the function of a room, such as lavatory in a bathroom or a sink in a kitchen, would constitute fixtures. ${ }^{97}$ However, those goods which were connected to the house merely by their connection to a utility supply (such as a light fitting, or a washing machine) could not evidence an intention to effect an improvement to the property, as well as being only partially attached to the property, and thus they remained goods. ${ }^{98}$ In the transcript of the decision, Roch LJ is recorded saying that 'items installed by a builder, e.g. the wall tiles will probably be fixtures, whereas items installed by e.g. a carpet contractor or curtain supplier or by the occupier of the building himself or herself may well not be'. ${ }^{99}$ This aspect is likely to turn on the facts of the particular case: for Haley 'this distinction seems both unhelpful and untenable'. ${ }^{100}$ On the former point, Roch LJ merely said that:

... [i] $\mathrm{t}$ must be remembered that in many cases the item being considered may be one that has been bought by the mortgagor on hire purchase, where the ownership of the item remains in the supplier until the instalments have been paid ... [and finding such goods to be fixtures] should only be made where the intent to effect a permanent improvement in the building is incontrovertible. ${ }^{101}$

For Haley, whilst the court took a 'common sense stance which was aimed, in the good common law tradition, to promote practical solutions to practical problems', ${ }^{102}$ Roch LJ's focus on the ownership status of the goods 'represents some departure from the traditional approach which largely ignored third party rights over the items'. ${ }^{103}$ Indeed, like the vice chancellor's approach, this seems unsupportable in light of the decisions in Melluish and Elitestone. Arguably, a distinction can be drawn on the basis that Botham concerned a residential mortgage, as opposed to the very different situations in Melluish and Elitestone. However, regardless of whether the Court of Appeal succeeded in its 'attempt to rationalise the law and to adapt long established wisdom and understandings to the realities of contemporary living, ${ }^{104}$ the problem of whether it is actually valid for a lender to extend its security, nominally focused on the land, to personal property, remains unresolved. It remains unclear whether the mortgagee can extend its security beyond the residential property to the goods therein. More recent decisions touching on this issue, though only from the commercial direction, clearly show the courts relying more on assertion than analysis.

In the 2011 case National Westminster Bank $v$ Hunter, ${ }^{105}$ Morgan J was faced with a mortgagee's attempt to realise its security over farmland, against a background of complex and opaque negotiations between the mortgagor, the mortgagee and third parties (with various actual, alleged and potential interests in the land). Morgan J refused to grant Hunter an order directing a sale of the land under the Law of Property Act 1925, s 91 (from Hunter to a company run by his wife), as it would have necessarily involved a breach of a contract Hunter had with one Taylor by virtue of an auction by a receiver. ${ }^{106}$ There was a second application, from the mortgagee, with regard to cattle that Hunter

\footnotetext{
97 Ibid D3.

98 Ibid D4.

99 Botham v TSB Bank (CA 30 July 1996) transcript 4-5.

100 Haley (n 35) 141.

101 Botham v TSB Bank (CA 30 July 1996) transcript 4.

102 Haley (n 35) 138.
}

103 Ibid 141.

104 Ibid 138.

105 [2011] EWHC 3170 (Ch). I am grateful to Professor Alison Clarke for alerting me to this case.

106 [2011] EWHC 3170 (Ch) [58]-[81]. 
was keeping on the pertinent land. The mortgagee sought an order under the Torts (Interference with Goods) Act 1977, s 13, which provides that, pursuant to s 12, the bailee can require that the bailor takes delivery of goods (Hunter was already subject to a County Court order to remove the cattle). ${ }^{107}$ Hunter argued that the s 12 requirement that the goods be 'in the possession or under the control of a bailee' prevented the granting of the order as he, Hunter, and not the mortgagee, was in possession and had control of the goods. Morgan J said that, whilst:

Hunter owns the cattle, the bank does not own the cattle and does not have a security interest in the cattle. At any rate, I proceed on that basis for today's purposes. But possession and control do not turn upon ownership, one man can be the owner and another can be in possession and a third can have control. ${ }^{108}$

As such Hunter's argument failed.

The reference to the mortgagee not having a security interest is interesting. The bank did not claim a security interest in the cattle; the action solely concerned the acquisition of possession of the realty. The nature of agricultural financing (and the lack of evidence of the content of the mortgage agreement) probably renders this decision sui generis. However, this decision suggests the possibility that mortgagees introduce terms into mortgages that provide them with powers over goods held on the realty, in order to protect themselves in the event that defaulting mortgagors fail to remove goods from the realty. ${ }^{109}$ Yet issues of control (i.e. the power to ensure vacant possession by the removal of goods) and ownership (i.e. whether the mortgagee of realty has a security interest in goods on the realty) are distinct issues which deserve different treatment. ${ }^{110}$

In Peel Land and Property (Ports No 3) Ltd v T S Sheerness Steel (Ports No 3) Ltd, ${ }^{111}$ the defendants had obtained a lease under which the original tenant covenanted to build a new steel-manufacturing facility. The claimants obtained the reversion of the lease and brought proceedings to prevent the defendants from disposing of plant and machinery on the site. The Court of Appeal allowed the claimant's appeal, on the grounds that at common law a tenant can remove any tenant's fixture, but that such a right depends on the terms of the lease (and determining the extent of the contractual terms is a process of ordinary contractual interpretation; no special words are required). Here the contract was sufficiently clear as to cover goods that became part of the demised property. Allowing the tenant to dispose of such goods would contradict the commercial obligation at the heart of the agreement (i.e. to build the new steel factory). ${ }^{112}$

107 Ibid [82], [89].

108 Ibid [85].

109 See e.g. Cumberland Consolidated Holdings Ltd v Ireland [1946] KB 264; Norwich Union Life Insurance Society v Preston [1957] 1 WLR 813; Scotland v Solomon [2002] EWHC 1886 (Ch); and below n 111.

110 The anonymous reviewer usefully pointed out that the mortgagee's power of disposal comes from their possessory interest over the land, which is not necessarily inconsistent with any ownership rights over the goods. This would mean the attempts by mortgagees to give themselves powers by the mortgage agreement are best characterised as exclusion clauses for tortious liability. The author acknowledges the strength of this argument, but this approach would seem to only operate in a mortgagee-mortgagor conflict, whereas a large volume of the case law has included a third-party owner of the goods, which necessitates focus on the ownership issue as well.

111 [2014] EWCA Civ 100; [2014] 2 P \& CR 8.

112 Three cases following Peel Land further emphasised that the alleged power of disposition in favour of mortgagees exists to enable efficient clearing or land or disposition of waste: Da Rocha-Afoduv Mortgage Express Ltd [2014] EWCA Civ 454; [2014] 2 P \& CR DG 10; Campbell v Redstone Mortgages Ltd [2014] EWHC 3081 (Ch); Mandalia v Beaufort Dedicated No 2 Ltd [2014] EWHC 4039 (QB). 
The importance of the degree of annexation to the land is further illustrated by the decision of the High Court in Lictor Anstalt v Mir Steel UK Ltd and Libala Ltd. ${ }^{113}$ There, the claimant had purchased equipment necessary to set up a steel mill and allowed a steel company $\mathrm{P}$ to assemble the equipment and use it to make steel products on land owned by P. The claimants and P later entered an agreement purporting to regulate P's use of the mill, which included a right for the claimant to remove the mill upon giving notice. P's administrators sold the land and the mill to the defendant. Asplin J held that the test for annexation from Holland and Elitestone would be used, making it difficult to conclude anything other than that the equipment was intended to be at least semipermanent. ${ }^{114}$ As the agreement between the claimant and $\mathrm{P}$ was intended to create contractual and equitable rights and obligations, they had done so and, thus, even though the mill had become part of the land, the agreement would still regulate the claimant's rights over the mill. ${ }^{115}$

\section{The effect of the bills of sale regime}

Individuals wanting to charge their goods must comply with the bills of sale legislation, ${ }^{116}$ which sets out certain requirements for this type of security: 117 'Speaking broadly [they] (1) avoid certain written instruments, (2) so far as they purport to create a security on personal chattels for the payment of money, unless (3) they comply with the conditions imposed by the Acts.' 118 The bill of sale, which has to be for more than $f, 30,119$ must have an attached schedule of the personal property covered by the bill, without which the bill will be void against third parties. ${ }^{120}$ However, these requirements do not cover growing crops, ${ }^{121}$ or '[a]ny fixtures separately assigned or charged' or any 'plant, or trade machinery' used in substitution for similar things that are covered in the bill of sale. ${ }^{122}$

113 [2014] EWHC 3316 (Ch).

114 Ibid [163]-[192].

115 Ibid [240]-[242]. At [293] Asplin J also held that the registration provisions of the Land Registration Act 2002, s 29(1), did not mean that the claimant's failure to register its interest was fatal: the claimant's rights were in the form of personal rights based on an economic tort. See also $n 78$ and accompanying text.

116 If the chargor is a company, then there are requirements concerning registration of the 'company charge' under the Companies Act 2006, s 860 . A bill of sale can be an outright transfer or a bill by way of security: see e.g. G S McBain, 'Repealing the Bills of Sale Acts' [2011] Journal of Business Law 475, 480-81.

117 Bills of Sale Act 1854, amended in 1866, and repealed by the Bills of Sale Act 1878, to which see further the Bills of Sale Act (1878) Amendment Act 1882 and the Bills of Sale Acts 1890 and 1891. The 1878 and 1882 Acts are to be read as if one statute, but to the extent that the 1878 Act is inconsistent with the later Act its provisions are repealed: Bills of Sale Act (1878) Amendment Act 1882, s 15. See also A Underhill and A Cole, Fisher's Law of Mortgage and Other Securities upon Property 6th edn (Butterworths 1910) 48: 'The Act of 1878 is usually called the principal Act, but the Act of $1882 \ldots$ so completely revolutionized the law of mortgage of personal chattels that ... it is really more important than the Act of 1878 . The Act of 1890, as amended by the Act of 1891, merely exempted certain commercial hypothecations from the operation of the Acts altogether.'

118 Underhill and Cole (n 117) 48. For a valuable recent overview of bills of sale, see Law Commission, Bills of Sale: A Consultation Document Law Com CP 225 (2015).

119 Bills of Sale Act (1878) Amendment Act 1882, s 12. Inflation has rendered this minimum value functionally meaningless, but it indicates that the original aim was to cover goods of some considerable value. Cf. McBain (n 116) 504, fn 233, and arguing for a minimum starting value of $f^{2000}$ if there is reform.

120 Bills of Sale Act (1878) Amendment Act 1882, s 4. The Bills of Sale Act 1878, if not adhered too, will make the bill of sale void but only as against the debtor and creditor, whereas failure to adhere to the 1882 Act makes the bill of sale void as against third parties. This difference in effect is correlative with the different underlying purposes of the different Acts: see text accompanying nn 19 and 20.

121 Bills of Sale Act (1878) Amendment Act 1882, s 6(1).

122 Ibid s 6(2). 
The bill of sale must be 'duly attested' and registered under the provisions of the Bills of Sale Act 1878 within seven days of execution of the bill of sale; ${ }^{123}$ attestation requiring one or more witnesses not a party to the bill itself. ${ }^{124}$ Failure to register the bill (and, indeed, to continue to update the bill every five years) renders it void. ${ }^{125}$ The bills must be in a prescribed form ${ }^{126}$ set out in a schedule to the 1878 Act, ${ }^{127}$ which is an essential aspect of a regime focused on documentation rather than transactions. Oral agreements for charges over personal property are outside this regime. ${ }^{128}$

The bills of sale legislation essentially prevents individuals granting effective floating charges over goods, ${ }^{129}$ not least because the requirement for a schedule of goods restricts bills of sale to already owned goods, ${ }^{130}$ but also because a charge simpliciter is not an assurance as required by the regime. ${ }^{131}$ So, whilst there may not be conceptual problems with individuals charging goods, ${ }^{132}$ the formal impossibility remains. Nevertheless, it remains peculiarly unclear as to whether future goods can be captured by the bills of sale regime. Future goods cannot be specified, and thus the formality requirements cannot be met, and so a bill over future goods is void. ${ }^{133}$ On the other hand, it has recently been held that equitable rights over future property are within the scope of the bills of sale regime, provided such rights are described with sufficient formality ${ }^{134}$ and substitutions of identified goods for improvement or maintenance of the security are allowed. ${ }^{135}$ Gullifer and Hurst describe the substitution exception as 'very limited',136 but, as the HSBC mortgage deed set out above indicates, the issue of substitutions may actually be of greater importance.

Whilst the ambit of the bills of sale regime in the modern era is extremely limited, ${ }^{137}$ the interaction between that regime and the law on fixtures was significant. ${ }^{138}$ The Bills

123 Bills of Sale Act (1878) Amendment Act 1882, s 8.

124 Ibid s 10.

125 See e.g. Halberstam v Gladstar Ltd [2015] EWHC 179 (QB).

126 Ibid s 9.

127 As to the importance of form, see e.g. Charlesworth v Mills [1892] AC 231; Chapman v Wilson [2010] EWHC $1746(\mathrm{Ch})$ (a document drawn by a solicitor failed to meet the formality requirements); L Gullifer and S Hurst, 'Bills of Sale Acts: Ripe for Reform?' (2013) 28(11) Journal of International Banking and Financial Law 685, 685: the 'stringent formal requirements . . . are extremely onerous'.

128 Law Commission (n 32) [8.7]; L Gullifer, Goode on Legal Problems of Credit and Security 5th edn (Sweet \& Maxwell 2013) [1-13], citing Reeves v Capper (1838) 5 Bing NC 136, 139; 132 ER 1057, 1058 (Tindal CJ); Flory v Denny (1852) 7 Ex 581, 585; 155 ER 1080, 1082 (Pollock CB); Newlove v Shrewsbury (1888) 21 QBD 41 (CA).

129 See e.g. P Giddins, 'Floating Mortgages by Individuals: Are They Conceptually Possible?' (2011) 3 Journal of International Banking and Finance Law 125; D Sheehan, 'The Abolition of Bills of Sale in Consumer Lending' (2010) 126 Law Quarterly Review 356.

130 Bills of Sale Act (1878) Amendment Act 1882, s 5.

131 E I Sykes, 'Suppressio Veri and Suggestio Falsi' (1957) 1 Melbourne University Law Review 80, 83: 'the mere charge over chattels is not a registerable bill of sale ... because it is not an assurance of chattels', citing Brown v Bateman (1866-67) LR 2 CP 272; Re Slee (1872-73) LR 15 Eq 69.

132 This is Giddins' conclusion (n 129), following Tailby v Official Receiver (1888) LR 13 App Cas 523, 541 (Lord Macnaghten).

133 Thomas v Kelly and Baker (1888) LR 13 App Cas 506.

134 Welsh Development Agency v Export Agency [1991] BCLC 936 (HL) 956-957 (Sir N Browne-Wilkinson VC); Chapman v Wilson [2010] EWHC 1746 (Ch) [95] (Vos J).

135 Seed v Bradley [1894] 1 KB 319; Coates v Moore [1903] 2 KB 140.

136 Gullifer and Hurst, 'Bills of Sale Acts' (n 127) 688, fn 8.

137 McBain (n 116) 477-79.

138 Arguably, for more so than what may be gleaned from the brief outline in e.g. McBain (n 116) 497. 
of Sale Acts from 1854 were aimed at preventing creditors from being defrauded by debtors remaining in possession of encumbered goods, ${ }^{139}$ but the policy shifted rapidly with the Bills of Sale Act (1878) Amendment Act 1882 preventing consumers from signing complicated documentation and, thus, unwittingly charging their personal property. ${ }^{140}$ This early form of 'consumer protection' was inappropriate for 'nonconsumer', i.e. commercial, borrowers, ${ }^{141}$ but judicial manipulation of the law on fixtures in order to take certain goods and transactions out of the aegis of the bills of sale regime had already been underway throughout the nineteenth century. ${ }^{142}$

Analysis of the case law leading up to Holland $v$ Hodgson ${ }^{143}$ shows that the underlying purpose of that decision (and those that followed it) was resolution of the relationship between the bills of sale regime and the law on mortgages for commercial debtors and creditors. In 1859 in Walmsley $v$ Milne, ${ }^{144}$ the land owner mortgaged land prior to installation of equipment to enhance his business as a brewer. By permanently attaching the goods to the realty, in order to enhance the realty, the goods had become part of the realty and could be taken by the mortgagee. The same result occurred in 1866 in Cullwick $v$ Swindell. ${ }^{45}$ In 1868 came Climie v Wood, ${ }^{146}$ a decision taken to be definitive in Holland v Hodgson, ${ }^{147}$ where Kelly CB in the Court of Exchequer stated that, whilst there were exceptions to the principle quicquid planatur solo, solo cedit for (inter alia) tenants and landlords:

no authority has been cited to shew that a mortgagor is entitled to remove such trade fixtures. There have been several cases where the courts have decided that, upon the true construction of the mortgage deeds, trade fixtures were removable by the mortgagor, but not one to shew that such right exists without a special provision. A mortgage is a security or pledge for a debt, and it is not unreasonable if a fixture be annexed to land at the time of a mortgage, or if the mortgagor in possession afterward annexes a fixture to it, that the fixtures shall be deemed an additional security for the debt whether it be a trade fixture or a fixture of any other kind. ${ }^{148}$

The importance of the nature of the agreement between the mortgagor and mortgagee is clear, as is the possibility of a mortgagor charging after-acquired personal property. In Longbottom v Berry, ${ }^{149}$ in 1869, the mortgagor acquired goods which were attached to the land for the purposes of improving the land's role in his business, after the land had been mortgaged to the defendant bank. Following this, the mortgagor assigned to the plaintiff his goods, under a duly registered bill of sale. After the mortgagor became bankrupt, the plaintiff took possession of the goods. The plaintiff and defendant agreed the goods should be sold; the court would determine entitlement to the fund. The Court of Queen's Bench held the goods that had been attached to the land (the overwhelming majority of

139 Cookson v Swire and Lees (1884) LR 9 App Cas 653, 664-66 (Lord Blackburn).

140 Thomas $v$ Kelly and Baker (1888) LR 13 App Cas 506, 514 (Lord Fitzgerald); The Manchester, Sheffield, and Lincolnshire Railway v North Central Wagon Company (1888) LR 13 App Cas 554, 560 (Lord Herschell); Charlesworth v Mills [1892] AC 231, 235 (Lord Halsbury LC). See also McBain (n 116) 482-85.

141 This remains problematic: Sheehan (n 129) 359; Gullifer and Hurst (n 127) 686. See also Companies Act 2006 (Amendment of Part 25) Regulations 2013 (SI 2013/600); Online Catering Ltd v Acton [2010] EWCA Civ 58.

142 M G Bridge, Personal Property Law 3rd edn (OUP 2002) 20. See e.g. In re Burdett (1888) 20 QBD 310 (CA).

143 (1872) LR 7 CP 328.

144 (1859) 7 CB NS 115; 141 ER 759.

145 (1866) LR 3 Eq 249 (approving Walmsley v Milne).

146 (1867-68) LR 3 Ex 257; (1868-69) LR 4 Ex 328.

147 (1872) LR 7 CP 328, 333.

148 (1867-68) LR 3 Ex 257, 260. See also (1868-69) LR 4 Ex 328, 330 (Willes J).

149 (1869) LR 5 QB 123. 
the enumerated chattels) passed to the mortgagee, following the approach set out in Walmsely and Cullwick. ${ }^{150}$ As to those goods not affixed to the land, they would pass to the plaintiff holder of the bill of sale. However, no separate justification for this was given; the clear implication was that the nature of the affixation was determinative. This approach, following the approval of Longbottom in Holland, would come to dominate thinking in this area.

In Holland $v$ Hodgson, the owner had mortgaged his real property to the plaintiff. Following this was an assignment of the owner's property to the defendants (who had taken as trustees for the benefit of the owner's creditors). The assignment was not registered as a bill of sale under the Bills of Sale Act 1854 and, thus, by s 1 it was void as against the defendants "so far as it was a transfer of "personal chattels" within the meaning of that Act', with the Act defining by s 7 that 'personal chattels' included fixtures. Thus, the court thought it 'properly admitted, that where there is a conveyance of the land the fixtures are transferred, not as fixtures, but as part of the land, and the deed of transfer does not require registration as a bill of sale'.151 The court also noted that the decision in Mather $v$ Fraser'152 had stood for some time, and '[i]t is of great importance that the law as to what is the security of a mortgagee should be settled ... we feel that it should not be reversed unless we clearly see that it is wrong'. ${ }^{153}$ Mather concerned the overlap between mortgage law and the law on bills of sale, but what is clear is that the point of the litigation in Holland was merely to avoid the problems caused by the Bills of Sale Acts. It is at least arguable that Holland's role as the leading authority for the meaning of fixtures must be limited, and that its true value lies in demonstrating the mechanism by which mortgagees can extend their security into personal property, i.e. by determining things to be fixtures.

Mather $v$ Fraser 154 concerned the status of machinery fixed to the floor of a factory. The vice chancellor, Sir W Page Wood, applied the basic rule that if goods had become annexed to the land they would become part of the realty and, thus, come under the mortgagee's interest. As to the argument that the failure to register the transfer of the machine as a bill of sale would void the agreement, he held that the Bills of Sale Act 1854 would not apply:

That Act only says that where a person makes a bill of sale of any part of his chattels, including fixtures, that bill of sale must be registered in a particular way. Here, no bill of sale was ever required to be made. A conveyance is made of the freehold, and that conveyance carries fixtures. To hold that an Act of Parliament, which says that, where bills of sale are used, they shall be dealt with in a particular manner, applies to a case where no such thing is used or required to be used, but where the whole of the property passes by the conveyance of the fee-simple would be to give a construction to the Act far beyond anything which was within its purview. 155

\footnotetext{
150 (1869) LR 5 QB 123127.

151 (1872) LR 7 CP 328, 333.

152 (1856) 2 K \& J 536; 69 ER 895.

153 (1872) LR 7 CP 328, 340.

154 (1856) 2 K \& J 536; 69 ER 895. Considered the leading case by Lord Macnaghten in Reynolds v Ashby [1904] AC 466, 471.

155 (1856) 2 K \& J 536, 558; 69 ER 895, 904-05.
} 
For the vice chancellor, ${ }^{156}$ the Bills of Sale Act 1854 was intended to deal with cases such as Exparte Sparrow, ${ }^{157}$ where a mortgage over all the personal property of the mortgagor had been granted, and the mortgagee was entitled to take possession upon default. The mortgagee did take possession, just before the mortgagor became bankrupt. The vice chancellor considered this to have been a 'very great convenience', ${ }^{158}$ and in Ex parte Sparrow Knight Bruce LJ 'expressed great doubt as to the validity of such provisions, unless the assignor had substantially other property besides that comprised in the deed, or was in solvent circumstances independently of that property'.159 The Bills of Sale Act 1854 was intended to solve this particular potential problem, ${ }^{160}$ but there is little in the way of clarification in the statutes of after-acquired goods. More importantly, the lack of appropriate delineation between consumer and commercial situations, though almost certainly anachronistic, is at the root of the current conceptual and practical problems.

Subsequent changes to the bills of sale regime did not lead to a change in judicial approach. In 1888 the Court of Appeal was faced with In re Yates, Batcheldor $v$ Yates. ${ }^{161}$ Here, the owner of land (which was used for business purposes) mortgaged the land without any reference to fixtures or trade machinery. Following the mortgagor's death, his creditors argued the mortgage was void as to the trade machinery, under the Bills of Sale Acts 1878 and 1882. Lindley LJ said:

where the mortgaged property includes valuable trade machinery ... [ $\mathrm{t}$ ]he question we have to decide is this, whether a mortgagee of a mill, under a mortgage framed as this is, can seize and sever and sell, apart from the land or mill, the trade machinery on it. If he can, then it strikes me, that, as regards trade machinery, it would be impossible to avoid the conclusion that this is a bill of sale, and void because it is not registered. ${ }^{162}$

Since the machinery passed only by virtue of being attached to the freehold, and the mortgage deed only provided a power of sale and not a power to possess the machinery as goods separate from taking possession of the freehold, the mortgage was not an assignment of the machinery. ${ }^{163}$ The key test was whether the goods had become fixtures, in which case they simply become part of the land, even if this test was more formal than functional. ${ }^{164}$ Thus, the mortgage was not a bill of sale within the meaning of the Acts and thus gave a valid security over the goods. However, judicial dislike for the legislative deeming, by s 5 of the 1878 Act, of trade machinery to be goods arguably caused judicial restriction of the debate over the extent to which goods become attached to land. ${ }^{165}$

156 Ibid 558-59; 905.

157 (1852) 2 De G M \& G 907; 42 ER 1127. Sir W Page Wood VC had been counsel in Ex parte Sparrow.

158 (1856) 2 K \& J 536, 559; 69 ER 895, 905.

159 (1852) 2 De G M \& G 907, 913; 42 ER 1127, 1129.

160 Cf. Meux v Jacobs (1875) LR 7 App Cas 481, 488 (Lord Chelmsford): 'It would be a most extraordinary conclusion for your Lordships to arrive at, that, because, for a particular purpose, that is to prevent frauds upon creditors, it is provided in the interpretation clause of an Act of Parliament [i.e. the Bills of Sale Act 1854] that fixtures are to be deemed personal chattels, therefore they are made personal chattels to all intents and purposes, and that also, as between mortgagor and mortgagee, they are personal chattels, although certainly these persons are not within the terms of the Act.'

161 (1888) LR 38 ChD 112.

162 Ibid 124.

163 Ibid 120 (Cotton LJ).

164 (1888) LR 38 ChD 112, 125 (Lindley LJ).

165 Ibid 127-29 (Bowen LJ). 
In re Yates was distinguished soon after in Small v National Provincial Bank of England, ${ }^{166}$ which concerned a conveyance of mortgaged land 'together with all and singular the fixed and moveable plant machinery and fixtures, implements and utensils now or hereafter fixed to or placed upon or used in or about the said hereditaments and premises'. The mortgagee had attempted to sell machinery in which the claimants had an interest as trustees for the mortgagor's creditors. In contrast to In re Yates, 'personal chattels are plainly assigned quâ chattels, and not as a portion of the land'. ${ }^{167}$ Stirling J dismissed an argument that the reference to fixtures in the deed was mere surplusage, ${ }^{168}$ thus, there had been an assignment of the machinery. The failure to register the deed as a bill of sale rendered it void, entitling the claimants to an injunction. ${ }^{169}$ Within a couple of months, In re Brooke came before Kekewich J. ${ }^{170}$ In Brooke the conveyance did mention machinery (unlike Yates), but it did not have the additional wording which enabled Stirling J to distinguish Small from Yates. ${ }^{171}$ Thus, Yates applied, and Kekewich J stated that:

... apart from any criticism of the words of the instrument, you cannot say that

fixed machinery which was conveyed to the mortgagee as part of the premises

to which it was attached is a separable part of the mortgaged property in the state

in which it was subjected to the mortgage. ${ }^{172}$

In Ellis $v$ Glover and Hobson Ltd, ${ }^{173}$ there was a mortgage of freehold land, with a covenant not to remove fixtures without the mortgagee's consent. Trade machinery was installed under a hire-purchase agreement: title would pass only on full payment and the vendor could remove the machinery in the event of default. Upon such removal, the mortgagee sued. It was held that the machinery had passed with the freehold. The Court of Appeal had to contend with the various opinions expressed in Hobson $v$ Gorringe and Reynolds $v$ Ashby, ${ }^{174}$ as well as its previous decision in Gough $v$ Wood. ${ }^{175}$ Whilst in Gough this permission to remove goods was implied, in Ellis no such implication was possible. Fletcher-Moulton LJ held so even though it gave rise to the potential for fraud on the part of the mortgagor and mortgagee as against third-party financiers of goods attached to the realty. ${ }^{176} \mathrm{He}$ based this on the difficulties faced by third parties in finding out if there was actually a mortgage over the relevant land ${ }^{177}$ and, whilst he thought estoppel might protect against fraud, he could see no case that went so far and, thus, he would rely on intervention from the legislature or the House of Lords to alter the law. ${ }^{178}$ In essence, there has to be an agreement to protect the mortgagee from claims that it had taken goods it was not entitled to, and this was the case here.

166 [1894] 1 Ch 686.

167 Ibid 691 (Stirling J).

168 Ibid.

169 Ibid 692.

170 [1894] 2 Ch 600.

171 Ibid 611.

172 Ibid 613.

173 [1908] 1 KB 388.

174 Ibid 394 (Fletcher-Moulton LJ).

175 [1894] 1 QB 713.

176 [1908] $1 \mathrm{~KB} 388,397$.

177 This is ultimately a historical problem in light of the modern system of registered land following the Land Registration Act 2002.

178 [1908] 1 KB 388, 398. Farwell LJ gave essentially the same reasoning regarding estoppel (398-400). 
Finally, it is worth noting Re Rogerstone Brick and Stone Co Ltd, ${ }^{179}$ as that case is cited by Cousins and Clarke as authority for the general rule that fixtures pass to the mortgagee. ${ }^{180}$ The Court of Appeal considered whether a debenture holder was entitled to the proceeds of sale of goods. The court held that a company's interest in goods as a mortgagor ended when the goods were sold by the mortgagee. The right of the mortgagee to remove fixtures, as against the company's lessor, did not infringe the Bills of Sale Acts. Younger J in the Chancery Division held it was 'clear that a mortgage of a lease by the lessee will carry with it the fixtures of the property which is in lease when the power to remove the fixtures is in the tenant', ${ }^{181}$ meaning in effect that the mortgagor in the course of a trade cannot remove fixtures as against the mortgagee, other than when goods are not owned by the mortgagor. ${ }^{182}$ In the Court of Appeal it was confirmed that the tenor of the mortgage was such that there was no separate right to the goods. ${ }^{183}$ The goods, as fixtures, did not have a sufficiently separate identity, though severance of the fixtures would suffice to enable the mortgagor to recover them at any point in the future. ${ }^{184}$

McBain suggests that the differentiation between trade and non-trade fixtures in the bills of sale regime was formulated in order to take into account a residence-based homeworkshop economy. ${ }^{185}$ However, the Victorian period, i.e. the relevant period for the doctrinal development considered herein, saw a massive shift away from homeworkshops and the putting-out system that necessitated such structures (and the authorities herein demonstrate that trade-fixture cases truly involved situations other than home-workshops): 186 'Once a place of production, new technology was turning the house into a place of consumption.' 187 There was significant change in the volume and nature of consumption of goods by individuals throughout the Victorian period. ${ }^{188} \mathrm{~A}$ considerable proportion of those new goods were connected to the home itself, cooking and cleaning implements, cutlery and crockery, and decorative and ornamental objects, ${ }^{189}$ alongside consumables such as drinks or foodstuffs. Some of these new goods would themselves increase consumption, ${ }^{190}$ and fashion began to exert its own power to enforce and enhance consumption. ${ }^{191}$ However, these changes in material culture did not have a substantive impact on judicial reasoning, which may simply be due to the (inevitably) greater volume of commercial disputes concerning commercial goods. The law had changed though, meaning that the courts, to protect commercial interests in light of an utterly inappropriate bills of sale regime, had to formulate procrustean rules for fixtures

\section{9 [1919] 1 Ch 110.}

180 See $n 19$.

181 [1919] 1 Ch 110, 119, following Meux v Jacobs (1875) LR 7 App Cas 481.

182 Following Ellis v Glover and Hobson Ltd [1908] 1 KB 388 and Reynolds v Ashby [1904] AC 466.

183 [1919] 1 Ch 110, 123 (Swinfen Eady MR).

184 Ibid 127-28 (Eve J).

185 McBain (n 116) 498.

186 J Flanders, The Making of Home (Atlantic Books 2014) 49-50, 84 (citing D Hussey and M Ponsonby, The Single Homemaker and Material Culture in the Long Eighteenth Century (Ashgate 2012) 85: noting that a Birmingham widow had a shop in her downstairs room and, as a file-maker, that it would have contained an anvil and bellows, but that this was in the early eighteenth century), 93, 98-100.

187 Flanders (n 185) 111. See also e.g. J Baudrillard, The System of Objects, J Benedict (trans) (Verso 2005) 69: 'The private realm of the household is indeed where the vast majority of our everyday objects are to be found.'

188 See e.g. A Briggs, Victorian Things (Batsford 1988); Flanders (n 186) ch 4, and especially at $140 \mathrm{ff}$ (noting the quantitative and qualitative increases in goods).

189 Briggs (n 188) 227. On the growth of cluttered living spaces, see e.g. Flanders (n 186) 136.

190 Flanders (n 186) 111-15.

191 Ibid 255 and cf. T Veblen, The Theory of the Leisure Class: An Economic Study of Institutions (Macmillan 1899). 
and fittings which could not provide an appropriate regime in light of the development of both a culture of consumerism of both land (in the form of residential consumer purchase-money mortgages) and goods.

\subsection{ARgUMENTS AGAINST ALLOWING MORTGAGEES TO ACQUIRE SECURITY INTERESTS IN PERSONAL PROPERTY}

If a mortgage agreement could cover after-acquired goods, mortgagees would benefit from the creation of an unregistered security interest which neither fits within the scheme of land registration ${ }^{192}$ nor within the current structure of security interests over goods. ${ }^{193}$ Yet, this is the effect of the nineteenth and early twentieth-century judicial attempts to carve out protection for commercial lenders in response to the bills of sale regime, under the guise of the application of an alleged doctrine of fixtures and fittings. The functional effect of this has been the creation of a loophole, enabling mortgages to cover after-acquired goods, and this appears to be what the HSBC mortgage agreement set out above is attempting to do. Furthermore, recent judicial preference for assertion over analysis has not clarified whether this is appropriate. Nevertheless, there are some suggestions that consumers should be able to grant a non-possessory security interest over their goods. ${ }^{194}$ It is argued that this is the wrong approach.

The shift in the relationship between commercial and consumer consumption of goods must be placed alongside historical understanding of real property ownership and control ideologies. As Fox notes, the 1925 property reforms 'provided the courts with the ideology, the language, the tools and the justification to adopt a presumption in favour of sale, to value land as a capital asset only, and to disregard the non-financial interests of occupiers in their homes'. 195 This ideology of property-commensurability focuses not on users (mortgagors), but on those concerned with the exchange value, i.e. creditors (mortgagees). ${ }^{196}$ The establishment of this ideology arguably prevented reassessment, in light of the substantial growth in mortgage-financed home-ownership, of the capacity of consumer residential mortgagors to charge after-acquired personal property by virtue of the initial residential purchase-price mortgage. This, combined with the growth in acquisition of goods, dislocated the commercially focused doctrine from the practical reality of personal property and consumer purchase-money mortgages.

English law affords only limited recognition to a concept of 'home'197 and has tended to subject the very notion of home to 'commercialism'. 198 However, the notion of home as a legally valuable concept has gained considerable academic traction. ${ }^{199}$ Whilst there

192 It is conceptually otiose to suggest that the only effective way in which the owner of goods can protect him or herself against the annexation of goods to land is by agreeing with the hirer that he or she can enter the land, and then registering that as a notice of an equitable right of entry. Cousins and Clarke (n 18) [15-02]; Harpum et al (n 18) [23-022]; Land Registration Act 2002, s 32(1); 9 [1914] 1 Ch 50 (approved in 9[1996] 1 AC 454, 475 (Lord Browne-Wilkinson)).

193 It would also appear to be 'anathema to Roman-Dutch law': D L Carey Miller, 'Fixtures and Auxiliary Items: Are Recent Decisions Blurring Real and Personal Rights?’ (1984) 101 South African Law Journal 205, 209.

194 Sheehan (n 129) 360. Sheehan recommends a registration system for security interests for consumers, modelled on the New Zealand Personal Property Security Act 1999.

195 Fox (n 8) 69.

196 Ibid 255-60.

197 Ibid 10-11.

198 Fox (n 8) 39-40 arguing that the changing emphasis from the Rent Acts to the Housing Acts in the 1980s indicated an ideological preference for the commercialisation of the real property market.

199 See generally Fox (n 8); Fox O’Mahony and Sweeney, The Idea of Home in Law (n 8). Cf. S M Stern, 'Residential Protectionism and the Legal Mythology of Home' (2008-2009) 107 Michigan Law Review 1093. 
are various conceptualisations of the elements that make up home, ${ }^{200}$ a key factor amongst others is how residential property provides unique canvases for the expression of self by the acquisition of things, ${ }^{201}$ a 'backdrop' for living. ${ }^{202}$ Things - goods - are props for living. Yet, the sentimentalising and, thus, the trivialisation of the concept of home make it easy to exclude the concept from legal analysis; ${ }^{203}$ this makes it in turn equally easy to devalue those props of life: goods. The laudable aims of those engaged in attempting to give greater legal value to the concept of home is acknowledged, but it is submitted that their position would only be strengthened through acknowledgment and utilisation of the importance and value of things in the development of a more comprehensive and accurate representation of a concept of home. ${ }^{204}$

The demonstrable personal relationship people can have with goods ${ }^{205}$ affects how people view their homes. ${ }^{206}$ Goods within the physical house are as important to the development of a home as the physical structure itself:207 'A house encompasses an array of different materials, from furniture and fixture to ornaments and décor, collectively creating a dwelling experience that is greater than the sum of its parts ... They are what transforms our house into our home. ${ }^{208}$ Even if the goods are peripheral, they can have a framing effect ${ }^{209}$ or a signalling function. ${ }^{210}$ Our relationships with things directly and indirectly reveal aspects of ourselves: ${ }^{211}$ 'possessions often remain profound and usually the closer our relationships are with objects, the closer our relationships are with people'. ${ }^{212}$ Serious individual, familial and social costs result from repossession of a house. 213 These costs would be exacerbated if the mortgagee could also repossess goods, the loss of which can also lead to serious psychological harm. ${ }^{214}$

200 See Fox (n 8) 23-24 and ch 4. As to the dynamic concept of 'home', see e.g. T Wikstrom, 'The Home and Housing Modernisation' in D N Benjamin, The Home: Words, Interpretations, Meanings, and Environments (Ashgate 1995) 268.

201 Flanders (n 186) 148-49, 253: 'The choice of goods, and how those goods were presented, were as important as the objects themselves.' See also Fox (n 8) 168-71; S Gosling, Snoop: What Your Stuff Says about You (Profile Books 2008) (the manner in which people display tangible goods within private and semi-private spaces is a strong indicator of personality type); Baudrillard (n 187) 13-14.

202 Fox (n 8) 3.

203 Ibid 24. See also e.g. Re Citro [1991] Ch 142, 150 (Nourse LJ).

204 It must be noted that, for example, the discussions of the dangers of repossession in the first three chapters of Fox O'Mahony and Sweeney, The Idea of Home in Law (n 8) fail to do this. One minor counter-example is in ibid 4, fn 16, noting that M J Radin, 'Property and Personhood' (1982) 34 Stanford Law Review 957 recognised the potential for confusion between real and personal property.

205 See e.g. Radin (n 204); R Belk, 'Possession and the Extended Self' (1988) 15 Journal of Consumer Research 139; C Jarrett, 'The Psychology of Stuff and Things' (2013) 26(8) The Psychologist 560, 560 (describing Belk's article as 'seminal'). See also e.g. Baudrillard (n 187) 91: 'our everyday objects are in fact objects of a passion - the passion for private property'.

206 See generally D Miller, Home Possessions: Material Culture Bebind Closed Doors (Berg 2001).

207 See generally Flanders (n 186).

208 A Hecht, 'Home Sweet Home: Tangible Memories of an Uprooted Childhood', in Miller (n 206) 123.

209 D Miller, Stuff (Polity Press 2010) 50-54.

210 See e.g. Baudrillard, The System of Objects (n 187). Cf. Miller (n 209) 12-13 (signalling is not the only function of things).

211 See e.g. Radin (n 204); Flanders (n 186).

212 D Miller, The Comfort of Things (Polity Press 2008) 1.

213 See e.g. J Ford, R Burrows and S Nettleton, Home Ownership in a Risk Society: A Social Analysis of Mortgage Arrears and Possessions (Policy Press 2001). See further Fox (n 8) ch 3, especially 109-22; Fox O’Mahony and Sweeney, The Idea of Home in Law: Displacement and Dispossession (n 8) and S Bright, 'Dispossession for Arrears: The Weight of Home in English Law' in Fox O'Mahony and Sweeney, The Idea of Home in Law (n 8).

214 See e.g. Belk (n 205) 143. See also R H Tawney, The Acquisitive Society (Harcourt, Brace \& Co 1920) 66-67. 


\section{Conclusion}

The consequence of the current doctrinal position is that mortgagors might not realise the extent mortgagees can control their goods, and the exercise of such control might have a disproportionately negative impact. As Lord Cozens-Hardy MR warned a century ago:

it certainly seems to me to savour of serfdom to say 'You shall not leave the house in which you are living without my consent; you shall not dispose of a chair or a table in your house on which I have no charge without my consent, and if you do the whole amount of principal and interest will immediately become payable instead of being payable by instalments. ${ }^{215}$

There are many factors that have impacted on this area of law, but it is clear that the law on fixtures and fittings and mortgages was heavily influenced by the effect of the bills of sale regime. Reform of the archaic bills of sale regime is essential ${ }^{216}$ and, although recent experience does not bode well, ${ }^{217}$ the Law Commission has begun the process of analysing the current regime with an aim to publishing recommendations for reform in the summer of $2016 .{ }^{218}$ It remains to be seen whether the specific problem identified in this article will be examined, let alone resolved, especially as the reform process is focused on the problems facing non-corporate creditors and debtors. ${ }^{219}$ Recent government intervention to protect persons from being dispossessed of their goods for non-payment of rent must be applauded. ${ }^{220}$ If this restriction is possible, then surely prohibitions on residential purchase-money mortgagees extending security over afteracquired goods must also be politically, if not judicially, possible. If mortgagees wish to have a right to remove goods from land in order to reduce waste or to enable efficient disposition of repossessed land, then they should be allowed to do so only in the narrowest fashion. This should take the form of an express agreement separate to the mortgage deed (rather than being a component part of the mortgage deed). For residential mortgages at least, this right should not be allowed to take the form of security over the goods themselves. If creditors wish to acquire security over goods, then they must be required to follow the requirements for such a transaction (and in such cases the proposals of the Law Commission on bills of sale would be broadly appropriate)..$^{221}$ The law of fixtures and fittings should not be used as a tool to avoid the strictures of personal property security law.

215 Horwood v Millar's Timber and Trading Co Ltd [1917] 1 KB 305, 312.

216 Law Commission (n 21) xiv. The flaws of the regime were identified almost immediately: Thomas $v$ Kelly and Baker (1888) LR 13 App Cas 506, 517 (Lord Macnaghten). See also McBain (n 116) 477: 'arguably, the [Bills of Sales Acts] comprise some of the worst legislative drafting of all time'. This legislative failure is compounded by the almost unusable state of the register itself: Gullifer and Hurst (n 127) 686-87.

217 Department for Business, Innovation and Skills, A Better Deal for Consumers: Consultation on Proposals to Ban the Use of Bills of Sale in Consumer Lending (2009) proposed abolition of the bills of sale regime for consumer lending. For an accurate critique, see Sheehan (n 129).

218 <http://www.lawcom.gov.uk/project/bills-of-sale> accessed 16 December 2015. The Law Commission published its consultation paper on this topic during the period that this article was under submission: Law Commission, Bills of Sale: A Consultation Paper Law Com CP 225 (2015). The consultation paper did not consider the issue at the heart of this article.

219 This focus of the reform was predicted in Gullifer and Hurst (n 127).

220 The Taking Control of Goods Regulations 2013 (SI 2013/1894). Perversely, it appears that some purchasers are restricted by the terms of their funding arrangements from adding to their property: B Lewis, 'Buyers "penalised" for Improving Home under Help to Buy' BBC News, 15 March 2015 <http://www.bbc.co.uk/news/uk-wales-politics-31870011> accessed 16 December 2015.

221 The author has responded to that consultation (in a joint response with Dr Orkun Akseli, Durham Law School). Economy unfortunately prevents a detailed examination of those proposals here. 
